\title{
Modulation of ionizing radiation induced oxidative imbalance by semi-fractionated extract of Piper betle An in vitro and in vivo assessment
}

\author{
Savita Verma,' Manju Lata Gupta,',* Ajaswrata Dutta,' Sanghmitra Sankhwar,' Sandeep Kumar Shukla' and Swaran J.S. Flora',* \\ 1Division of Radiation Biosciences; Institute of Nuclear Medicine and Allied sciences; Brig. S.K Mazumdar Marg, Delhi India; ${ }^{2}$ Division of Pharmacology \\ and Toxicology; Defence Research and Development Establishment; Gwalior, India
}

Key words: oxidative stress, Piper betle, ionizing radiation, lipid peroxidation, glutathione

\begin{abstract}
Abbreviations: PBL, Piper betle leaf; SOD, superoxide dismutase; MN, micronuclei; DPPH, 1,1-diphenyl-2-picryl hydrazyl; BSA, bovine serum albumin; BHT, butylated hydroxy toluene; GSH, reduced glutathione; FCR, folin ciocalteu reagent; TCA, trichloroacetic acid; TBA, thiobarbituric acid; NBT, nitro blue tetrazolium chloride; DMSO, dimethyl sulfoxide; LPx, lipid peroxidation; GSSG, oxidized glutathione; TBARS, thiobarbituric acid reactive species; GAE, gallic acid equivalent
\end{abstract}

\begin{abstract}
The study was planned to evaluate modulatory effect of aqueous extract of Piper betle leaf (PBL) on ionizing radiation mediated oxidative stress leading to normal tissues damage during radiotherapy and other radiation exposures. The total polyphenols and flavonoids known as free radical scavenger (chelators) were measured in the extract. To ascertain antioxidant potential of PBL extract, we studied free radical scavenging, metal chelation, reducing power, lipid peroxidation inhibition and ferric reducing antioxidant properties (FRAP) using in vitro assays. Mice were exposed to varied radiation doses administered with the same extract prior to irradiation to confirm its oxidative stress minimizing efficacy by evaluating ferric reducing ability of plasma, reduced glutathione, lipid peroxidation and micro-nuclei frequency. PBL extract was effective in scavenging DPPH (up to $92 \%$ at $100 \mu \mathrm{g} / \mathrm{ml}$ ) and superoxide radicals (up to $95 \%$ at $80 \mu \mathrm{g} / \mathrm{ml}$ ), chelated metal ions (up to $83 \%$ at $50 \mu \mathrm{g} / \mathrm{ml}$ ) and inhibited lipid peroxidation (up to $45.65 \%$ at $500 \mu \mathrm{g} / \mathrm{ml}$ ) in a dose dependant manner using in vitro model. Oral administration of PBL extract $(225 \mathrm{mg} / \mathrm{kg}$ body weight $) \mathrm{I} \mathrm{hr}$ before irradiation in mice significantly enhanced $(p<0.0 \mathrm{I})$ radiation abated antioxidant potential of plasma and GSH level in all the observed organs. The treatment with extract effectively lowered the radiation induced lipid peroxidation at $24 \mathrm{hrs}$ in all the selected organs with maximum inhibition in thymus $(\mathrm{p}<0.0 \mathrm{I})$. After $48 \mathrm{hrs}$, lipid peroxidation was maximally inhibited in the group treated with the extract. Frequency of radiation induced micronucleated cells declined significantly $(34.78 \%, p<0.0 \mathrm{I})$ at $24 \mathrm{hrs}$ post-irradiation interval by PBL extract administration. The results suggest that PBL extract has high antioxidant potential and relatively non-toxic and thus could be assertively used to mitigate radiotherapy inflicted normal tissues damage and also injuries caused by moderate doses of radiation during unplanned exposures.
\end{abstract}

\section{Introduction}

Radiotherapy is an integral part of cancer treatment. However, its damaging effects on normal tissues also cannot be ignored. Extensive work, since decades, for abating normal tissue injuries inflicted during radiotherapy and other unplanned radiation exposure, has been put into. Result of this endeavor, though has not gone fruitless but encouraging output is still awaited. Synthetic drugs evaluated to meet this target, were found toxic hence, could not be put into the use. ${ }^{1-3}$ Herbs rich in antioxidants and minimally toxic in nature are on extensive search to fulfill the need. Piper betle leaves in their unprocessed form are eaten almost daily for centuries in many parts of the world. Higher doses of this plant extract, used for many consecutive days in animals, are also found non toxic. ${ }^{4,5}$
Ionizing radiation, used in radiotherapy, may induces reactive oxygen species (ROS)/reactive nitrogen species (RNS) leading to oxidative injury to the basic cellular macromolecules such as lipids, proteins and DNA, inflicting cellular dysfunction and ultimately cell death. ${ }^{6}$ Excessive production of oxidative stress has been implicated in many pathological disorders other than cancer, such as ageing, rheumatoid arthritis, chronic fatigue syndrome, psoriasis, asthma, cardiovascular diseases, Parkinson's disease, Alzheimer's disease etc. ${ }^{7}$ Low LET (linear energy transfer) radiation causes damage through ROS production mainly by the radiolysis of water present in living system. ${ }^{8}$ In the presence of oxygen, the condition becomes adverse by the generation of other reactive species such as superoxide radicals $\left(\mathrm{O}_{2}^{-}\right)$and singlet oxygen $\left({ }^{1} \mathrm{O}_{2}\right)$. To counter the deleterious effect of free radicals, cells and tissues are equipped with endogenous defense enzymatic 


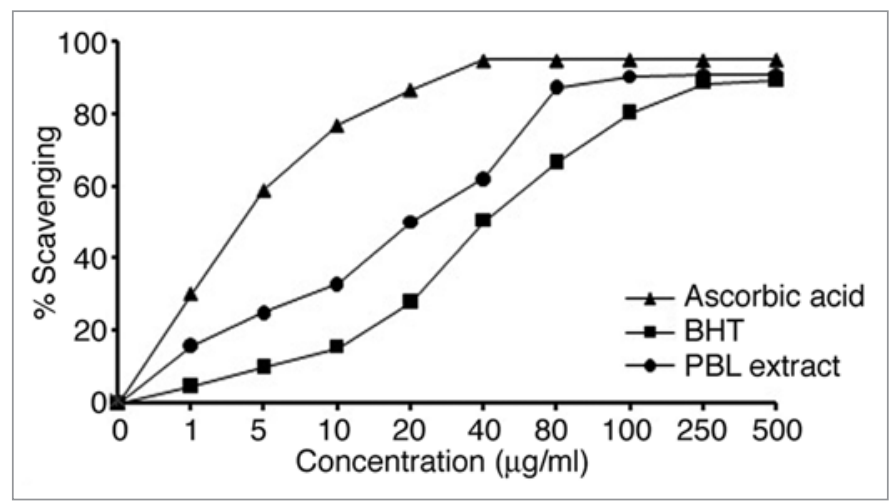

Figure I. DPPH free radical scavenging activity of different concentrations of Piper betle leaf (PBL) extract. Ascorbic acid and BHT, the standard antioxidants, were used as positive controls. Methanolic solution of DPPH, mixed with PBL extract/standards, was incubated at room temperature. Decrease in absorbance was measured at $517 \mathrm{~nm}$ against methanol. The absorbance of DPPH was considered as $0 \%$ inhibition. PBL showed higher DPPH radical scavenging activity as compared to BHT but lower than ascorbic acid. Each value represents mean \pm SEM of data from three independent experiments.

and non-enzymatic antioxidants such as glutathione, vitamin C, $\alpha$-tocopherol, superoxide dismutase (SOD), catalase, glutathione peroxidase etc. However, under extreme condition, endogenous defense system of the body gets dearranged and becomes inefficient to cope up with the free radical attack resulting to oxidative imbalance. This spurred the interest for exogenous supply of antioxidants to minimize oxidative damages. Many herbs, like Podophyllum hexandrum, Hippophae rhamnoides, Emblica officinalis, Zingiber officinale, Osimum sanctum, Tinospora cordifolia, Phyllanthus amarus, Centella asiatica etc., used in ayurvedic treatment are reported to contain plethora of secondary metabolites which could be useful in reducing ionizing radiation induced oxidative damages.

Piper betle (Family: Piperaceae), a perennial climber commonly known as paan, is mainly cultivated in most parts of Southeast Asia.9 The leaves of Piper betle are reported to contain catechin, eugenol, allylpyrocatecol and hydroxychavical which are beneficial to human health in many ways. The leaves act as a good remedy against bad breath and also reported to be digestive, pancreatic lipase stimulant ${ }^{9,10}$ and hepatoprotective. ${ }^{11}$ The leaf extract was found to diminish the effect of oxidative stress by elevating the level of endogenous defense enzymes, ${ }^{5}$ scavenging free radicals and acting as a good immunomodulatory agent. ${ }^{12}$ Recently, Piper betle leaf extract was also reported to inhibit gamma radiation induced damage in plasmid DNA and lipid peroxidation in rat liver mitochondria under in-vitro conditions. ${ }^{13}$

The present study was aimed at evaluating potential of PBL extract in minimizing radiation induced normal tissue injuries inflicted during radiotherapy and other radiation exposures. The stress modifying properties of PBL extract were evaluated by measuring the degree of protection to plasma antioxidant potential, cellular membrane damage and non enzymatic antioxidants in mice exposed to total body irradiation. Moderate dose of gamma rays (500 cGy) was used as oxidative stress inducing agent. An

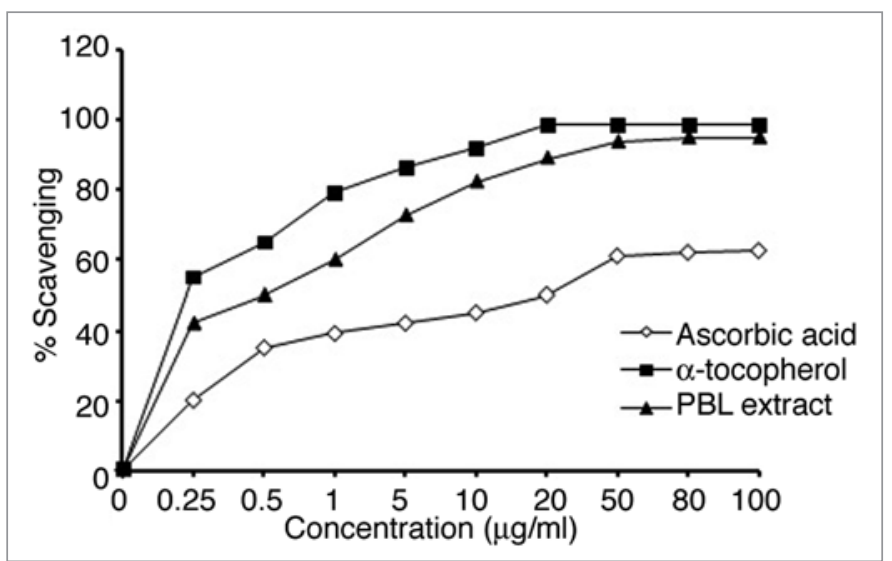

Figure 2. Superoxide radicals scavenging activity of Piper betle leaf (PBL) extract. BHT and $\alpha$-tocopherol were used as standards for reference. Varied concentrations of PBL extract/standards were mixed with DMSO and NBT. Formation of purple colored diformazan was measured at $560 \mathrm{~nm}$. The \% scavenging activity of formation of colored complex was calculated with respect to control in all the samples.

Values are expressed as mean \pm SEM of data from three independent assays. Superoxide scavenging activity shown by PBL was found higher to BHT but less than $\alpha$-tocopherol.

array of in vitro assays was used to confirm oxidative stress mitigating potential of PBL extract by screening its properties of scavenging free radicals, chelating transition metal ions, inhibiting lipid peroxidation and reduction potential.

\section{Results}

In vitro studies. The results obtained from the present study reveal that the aqueous extract of PBL has adequate amounts of phenolic and flavonoids content. The total phenolic contents in terms of gallic acid equivalent was found to be $397.98 \pm 19.26 \mu \mathrm{g}$ GAE/mg (the standard curve equation: $y=0.0225 x-0.1164$, $\left.\mathrm{r}^{2}=0.9315\right)$ and the total flavonoids content estimated in terms of quercetin equivalent was $265 \pm 15.72 \mu \mathrm{g} \mathrm{QE} / \mathrm{mg}$ (the standard curve equation: $\left.\mathrm{y}=0.0008 \mathrm{x}+0.0621, \mathrm{r}^{2}=0.9867\right)$.

Antioxidant potential of extract. DPPH free radical scavenging activity. PBL extract showed maximum DPPH radicals scavenging activity up to $90.2 \%$ at $100 \mu \mathrm{g} / \mathrm{ml}$ concentration while it was $94.3 \%$ at $40 \mu \mathrm{g} / \mathrm{ml}$ for ascorbic acid and $89.2 \%$ for BHT at much higher concentration $(500 \mu \mathrm{g} / \mathrm{ml})$ (Fig. 1). The $\mathrm{IC}_{50}$ values observed were $37.9 \mu \mathrm{g} / \mathrm{ml}\left(\mathrm{y}=0.8015+9.689, \mathrm{r}^{2}=0.9852\right)$ for PBL extract, $5.02 \mu \mathrm{g} / \mathrm{ml}\left(\mathrm{y}=0.7450+3.652, \mathrm{r}^{2}=0.9721\right)$ for ascorbic acid and $57.12 \mu \mathrm{g} / \mathrm{ml}\left(\mathrm{y}=0.7414 \mathrm{x}+7.7285, \mathrm{r}^{2}=0.9483\right)$ for BHT. The $\mathrm{IC}_{50}$ value of the extract was higher than ascorbic acid but lower than BHT, revealing that the extract had higher free radical scavenging potential than BHT but lesser than ascorbic acid.

Superoxide scavenging activity. The superoxide scavenging activity as reflected in Figure 2 shows that the extract has exhibited the maximum scavenging activity $(95 \%)$ at $80 \mu \mathrm{g} / \mathrm{ml}$ concentration. For BHT the maximum scavenging activity was recorded $62 \%$ at $50 \mu \mathrm{g} / \mathrm{ml}$ concentration whilst for $\alpha$-tocopherol it was $98.7 \%$ at $20 \mu \mathrm{g} / \mathrm{ml}$ concentration. $\mathrm{The} \mathrm{IC}_{50}$ values observed were 


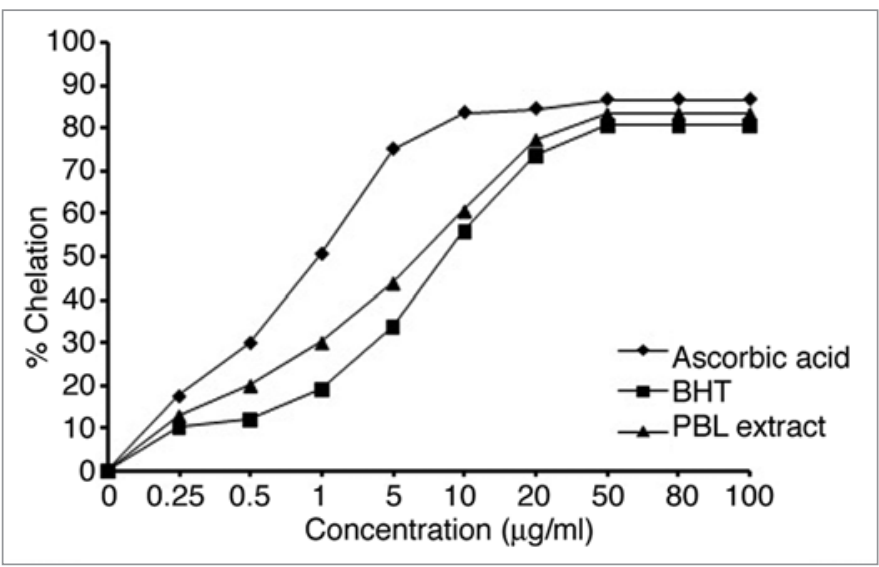

Figure 3. Effect of varying concentrations of Piper betle leaf (PBL) extract on chelation of metal ions (iron). BHT and ascorbic acid were used as positive controls. Methanolic solution of o-phenanthroline and ferric chloride $(200 \mu \mathrm{M})$, mixed with extract/standards, was incubated for $10 \mathrm{~min}$ at room temperature. Absorbance was recorded at $510 \mathrm{~nm}$ and percent chelation was calculated with respect to control. PBL extract showed marginally lower metal chelation activity as compared to ascorbic acid but higher than BHT. Results are expressed in terms of concentration vs. \% chelation. Each value represents mean \pm SEM of three independent experiments.

$3.59 \mu \mathrm{g} / \mathrm{ml}\left(\mathrm{y}=9.3465+16.599, \mathrm{r}^{2}=0.9491\right)$ for PBL extract, $6.86 \mu \mathrm{g} / \mathrm{ml}\left(\mathrm{y}=6.1958+7.5792, \mathrm{r}^{2}=0.9899\right)$ for BHT and $2.35 \mu \mathrm{g} / \mathrm{ml}\left(\mathrm{y}=6.1969+7.5780, \mathrm{r}^{2}=0.9785\right)$ for $\alpha$-tocopherol. The superoxide scavenging activity of the extract was less than $\alpha$-tocopherol but higher than BHT.

Metal chelation activity. The percent metal chelation activity as shown in Figure 3 indicates that the extract reflected its maximum activity $(83.3 \%)$ at $50 \mu \mathrm{g} / \mathrm{ml}$ concentration while for ascorbic acid and BHT it was $87 \%$ and $80.3 \%$ respectively at the same concentration. $\mathrm{IC}_{50}$ values for extract, ascorbic acid and BHT were analyzed as $5.6 \mu \mathrm{g} / \mathrm{ml}\left(\mathrm{y}=10.413 \mathrm{x}-7.8282, \mathrm{r}^{2}=0.9517\right)$, $4.5 \mu \mathrm{g} / \mathrm{ml}\left(\mathrm{y}=10.049 \mathrm{x}-12.682, \mathrm{r}^{2}=0.9756\right)$ and $6.0 \mu \mathrm{g} / \mathrm{ml}$ $\left(y=10.608 x-13.712, r^{2}=0.9381\right)$ respectively, indicated that the metal chelation activity of the extract was higher than BHT but marginally lower than ascorbic acid.

Anti-lipid peroxidation activity. In the current study, the degree of lipid peroxidation was assayed by measuring percent inhibition of thiobarbituric acid reactive species (TBARS). The maximum inhibition activity of PBL extract was $45.65 \%$ at $500 \mu \mathrm{g} / \mathrm{ml}$ concentration while it was $48.69 \%$ for BHT at the same concentration (Fig. 4). The $\mathrm{IC}_{50}$ values observed to be $11.76 \mu \mathrm{g} / \mathrm{ml}\left(\mathrm{y}=4.5 \mathrm{x}-2.9286, \mathrm{r}^{2}=0.9556\right)$ for extract and $10.37 \mu \mathrm{g} / \mathrm{ml}\left(\mathrm{y}=4.28 \mathrm{x}+3.1234, \mathrm{r}^{2}=0.9532\right)$ for BHT. The anti-lipid peroxidation activity of the extract was found to be approximately same as that of the standard antioxidant BHT.

Reducing power assay. As reflected in Figure 5 the reducing power of PBL extract was maximum (1.64) at $1,000 \mu \mathrm{g} / \mathrm{ml}$ concentration which was nearly similar to standard BHT (1.11) at the same concentration.

FRAP assay. The extract has shown high potential of reducing ferric (III) form of iron to ferrous (II) (Fig. 6). In the presence of PBL extract TPTZ-Fe (III) complex was reduced to TPTZ-Fe

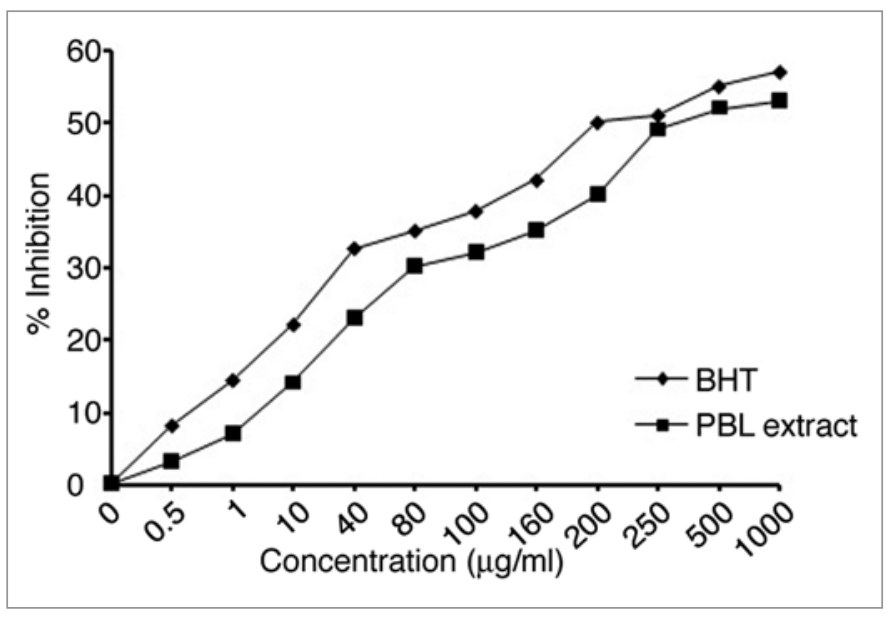

Figure 4. Anti-lipid peroxidation activity of different concentrations of Piper betle leaf (PBL) extract. BHT was used as standard for comparison. Mouse brain homogenate, was added to various concentrations of PBL extract/BHT, and mixed with $2 \mathrm{ml}$ of TBA-TCA solution. Thereafter, the mixtures were boiled, cooled and centrifuged. The resultant pink colored Formozan was measured at $536 \mathrm{~nm}$. Percent inhibition of lipid peroxidation was calculated with respect to control. Anti-lipid peroxidation activity of PBL extract was nearly similar to standard BHT. Each value represents mean \pm SEM of three independent experiments.

(II) complex (i.e., ferrous tripyridyltriazine complex). The ferric reducing antioxidant property as shown by the extract was more or less similar to the standard BHT (non-significant) but weaker than ascorbic acid $(90 \%, \mathrm{p}<0.001)$ and quercetin $(86 \%, \mathrm{p}<$ 0.001) used as standards (Fig. 6).

In-vivo studies. Ferric reducing ability of plasma (FRAP). Figure 7 depicts ferric reducing ability of plasma in saline treated, radiation only and PBL treated irradiated groups at different time intervals. Radiation exposure to 500 cGy led to $40 \%$ ( $\mathrm{p}<0.01$ ) reduction within $24 \mathrm{hrs}$ in ferric reducing ability of plasma as compared to untreated animals (Fig. 7). Though, after $48 \mathrm{hrs}$ of irradiation, the recovery in irradiated group also started but the FRAP values were still markedly less than the controls. Pretreatment of PBL extract significantly $(34 \%, \mathrm{p}<0.05)$ countered the radiation induced decline in ferric reducing ability of plasma even after $24 \mathrm{hrs}$ of irradiation and the FRAP values were almost normal after $48 \mathrm{hrs}$.

Glutathione (GSH). In radiation exposed mice, $24 \mathrm{hrs}$ post irradiation, glutathione level had fallen apparently in all the observed vital organs as compared to control and the similar trend continued up to 48 hrs (Table 1). In whole blood, liver, kidney and jejunum GSH content decline within $24 \mathrm{hrs}$ of irradiation was $3-5 \%$ as compared to saline treated control group. However, in thymus this fall in GSH concentration was much more drastic (74\%). Pretreatment of mice with PBL extract one hour before irradiation resulted up to $5 \%$ increase in GSH concentration in all the major organs even after $24 \mathrm{hrs}$ while in thymus GSH had elevated by $84 \%(\mathrm{p}<0.001)$ at the same interval of study.

Lipid peroxidation (LPx). Exposure to $500 \mathrm{cGy}$ irradiation led to considerable induction of lipid peroxidation in all the observed organs of total body irradiated mice (Table 2). After 24 hrs of 


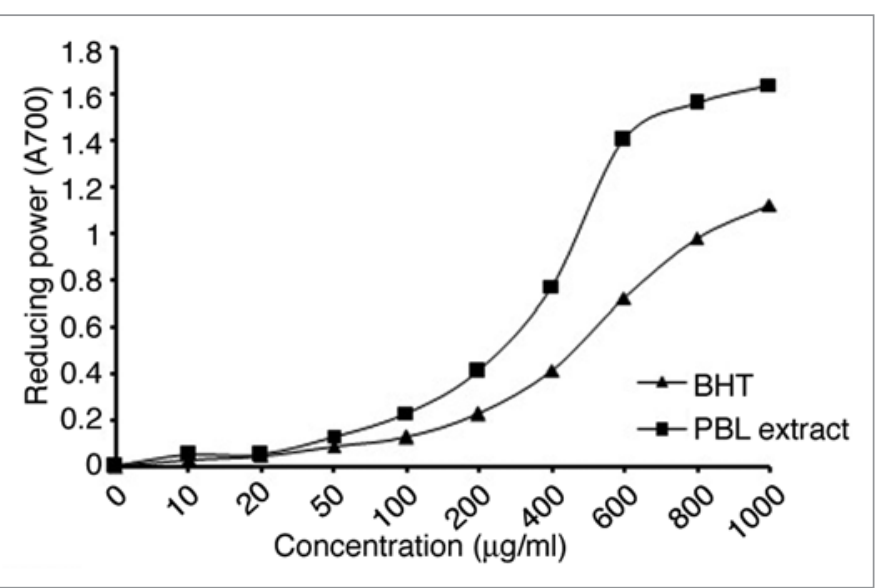

Figure 5. Reducing power of Piper betle leaf (PBL) extract compared with standard antioxidant $\mathrm{BHT}$ by spectrophotometric detection of $\mathrm{Fe}^{3+}$ $\mathrm{Fe}^{2+}$ transformation. Different concentrations of PBL extract/BHT, after incubation with potassium ferricyanide, were mixed with $10 \%$ TCA. After administration of ferric chloride, absorbance was measured at $700 \mathrm{~nm}$ against blank. Reducing power of PBL was found nearly similar to $\mathrm{BHT}$. Results are expressed in terms of concentration vs. absorbance. Each value represents mean \pm SEM of three independent experiments.

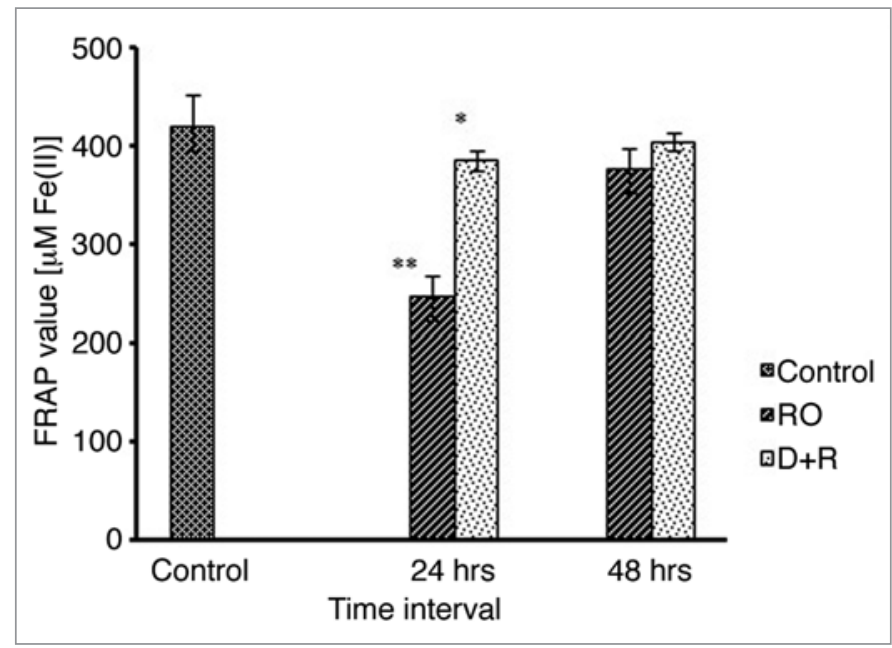

Figure 7. Effect of Piper betle leaf (PBL) extract on ferric reducing ability of plasma in mice of different treated groups. Swiss albino female mice were divided into three groups: control, radiation only $(\mathrm{RO})$ and $\mathrm{PBL}$ extract pretreated irradiated $(D+R)$. Plasma separated from the blood of each mouse, mixed with FRAP solution and incubated in dark. Absorbance was recorded at $593 \mathrm{~nm}$. Formation of $\mu \mathrm{M} \mathrm{FeSO}_{4}$ was calculated based on standard curve. Pre-irradiation treatment of animals with PBL significantly protected the antioxidant potential of plasma. Data was pooled and analyzed by three independent experiments having three animals in each group. Values are represented as mean \pm S.D. ${ }^{*} p<0.05$, radiation only (RO, $24 \mathrm{hrs}$ ) vs. control (saline treated). ${ }^{* *} \mathrm{p}<0.0 \mathrm{l}$, radiation $+\mathrm{PBL}$ treated (D + R, 24 hrs) vs. radiation only ( $R O, 24$ hrs).

irradiation, most of the organs reflected significantly elevated level of malondialdehyde in radiation only group which continued up to $48 \mathrm{hrs}$. In this group, after $24 \mathrm{hrs}$, malondialdehyde concentration in thymus, brain and jejunum was enhanced by $65 \%$ $(\mathrm{p}<0.001), 51 \%(\mathrm{p}<0.001)$ and $53 \%(\mathrm{p}<0.001)$ respectively.

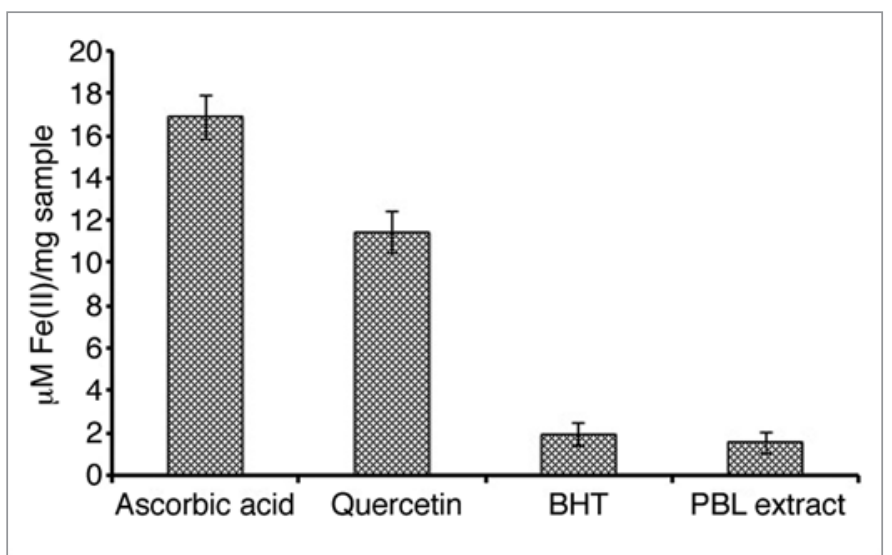

Figure 6. Ferric reducing antioxidant property of Piper betle leaf (PBL) extract was evaluated by its ability to reduce TPTZ-Fe (III) complex to TPTZ-Fe (II). Ascorbic acid, quercetin and BHT were used as standards. FRAP solution (acetate buffer + TPTZ + ferric chloride) mixed with extract/standards, was incubated in dark. Formation of the colored product (ferrous tripyridyltriazine complex) was measured at $593 \mathrm{~nm}$. Values are expressed as mean \pm SEM. Experiment was repeated in triplicate. Ferric reducing antioxidant property of PBL extract was found weaker as compared to ascorbic acid and quercetin but higher than BHT.

In liver and kidney, increase in LPx activity was up to $40-43 \%$ $(\mathrm{p}<0.01)$. Pre-treatment of PBL extract in whole body irradiated mice exhibited significant decrease (10-15\%) in LPx even after $24 \mathrm{hrs}$ of study in majority of the organs. But in thymus LPx inhibition was recorded up to $34 \%$ in this group. However, lipid degradation values could not be restored to normalcy up to $48 \mathrm{hrs}$ of study in this group.

Micronucleus (MN) assay. Micronuclei frequency was found enhanced $(\mathrm{p}<0.001)$ in mouse bone marrow cells in radiation only group $(23.33 \pm 1.86 \%)$ as compared to controls $(1.16 \pm$ $0.75 \%)$ at $24 \mathrm{hrs}$ post irradiation interval. However, pre-irradiation treatment of PBL extract significantly $(\mathrm{p}<0.01)$ lowered the micronucleated cells $(15 \pm 1.63 \%)$ in comparison to radiation exposed group (Fig. 8).

\section{Discussion}

Plethora of synthetic and herbal extracts is extensively screened to minimize radiation induced deterministic and stochastic effects developed after radiotherapy and other unplanned radiation exposures. ${ }^{1,2}$ In principle, free radicals generated during radiation exposure initiate adverse changes which, in due course, lead to the generation of immediate and late effects depending on the quantum of radicals. Though antioxidant and radioprotective potential of various extracts of Piper betle based on in vitro systems have been moderately evaluated, ${ }^{5,11,13,14}$ but to the best of our knowledge modulation of ionizing radiation induced damage in vivo was attempted for the first time in the present study.

Measurement on total polyphenols and flavonoids in PBL extract demonstrated their presence in rich quantities. Flavonoids are reported to bear wide spectrum of antioxidant properties like they act as free radical scavenger by rapid donation of hydrogen 
Table I. Effect of pre-irradiation administration of aqueous extract Piper betle leaf (PBL) (225 mg/kg b.w., -I hr) on radiation altered GSH level in different tissues of Swiss albino female mice at different time intervals

\begin{tabular}{|c|c|c|c|c|c|c|c|c|}
\hline & Group & Thymus & Spleen & Whole blood & Brain & Liver & Kidney & Jejunum \\
\hline & Control & $50.6 \pm 3.84$ & $18.3 \pm 1.57$ & $\mid 2.2 \pm 1.31$ & $3.3 \pm 0.77$ & $6.9 \pm 0.95$ & $9.0 \pm 1.97$ & $8.6 \pm 1.39$ \\
\hline \multirow{2}{*}{$24 \mathrm{hrs}$} & Radiation only & $13.4 \pm 0.7 \mathrm{I}^{\mathrm{a}^{* * * *}}$ & $13.4 \pm 1.53^{2^{* *}}$ & $9.9 \pm 0.33^{\mathrm{a}^{*}}$ & $3.3 \pm 0.89$ & $5.3 \pm 0.32$ & $6.4 \pm 0.57^{\mathrm{a}^{*}}$ & $6.6 \pm 0.29^{a^{*}}$ \\
\hline & Radiation + PBL treated & $56.5 \pm 3.93^{b^{* * * *}}$ & $16.0 \pm 1.21$ & $10.8 \pm 0.92$ & $4.1 \pm 1.00$ & $8.9 \pm 0.63^{b^{*}}$ & $9.8 \pm 0.60^{\mathrm{b}^{*}}$ & $6.3 \pm 0.37$ \\
\hline \multirow{2}{*}{$48 \mathrm{hrs}$} & Radiation only & $|4.9 \pm 0.7|$ & $14.0 \pm 1.79$ & $9.4 \pm 1.05$ & $3.2 \pm 0.20$ & $6.2 \pm 1.12$ & $7.4 \pm 1.86$ & $6.3 \pm 1.50$ \\
\hline & Radiation + PBL treated & $57.1 \pm 3.38^{\mathrm{c}^{* * * *}}$ & $15.1 \pm 1.62$ & $11.6 \pm 1.33^{c^{*}}$ & $4.9 \pm 0.85$ & $7.7 \pm 1.52$ & $9.8 \pm 0.59^{c^{*}}$ & $10.7 \pm 0.98^{\mathrm{c}^{* *}}$ \\
\hline
\end{tabular}

The supernatants of individual tissue homogenate were mixed with DTNB; Appearance of yellow color was measured spectrophometrically at $4 \mathrm{I} 2 \mathrm{~nm}$; Values are expressed as $\mu \mathrm{g} G S H / m g$ protein and level of significance of the difference is indicated in terms of $p$-values; Data represents mean \pm SD of three independent experiments containing three animals in each group; ${ }^{a}$ radiation only (24-hrs) vs. control (saline treated); ${ }^{b}$ radiation + PBL treated $(24 \mathrm{hrs})$ vs. radiation only $(24 \mathrm{hrs})$; ${ }^{c}$ radiation $+\mathrm{PBL}$ treated $(48 \mathrm{hrs})$ vs. radiation only $(48 \mathrm{hrs}) ;{ }^{*} \mathrm{p}<0.05,{ }^{* *} \mathrm{p}<0.0 \mathrm{l},{ }^{* * * *} \mathrm{p}<0.00 \mathrm{I}$.

Table 2. Effect of pre-irradiation administration of PBL extract ( $225 \mathrm{mg} / \mathrm{kg}$ b.w., -I hr) on inhibition of lipid peroxidation in different tissues of Swiss albino female mice

\begin{tabular}{|c|c|c|c|c|c|c|c|}
\hline & Group & Thymus & Spleen & Brain & Liver & Kidney & Jejunum \\
\hline & Control & $0.14 \pm 0.001$ & $0.20 \pm 0.034$ & $0.18 \pm 0.002$ & $0.04 \pm 0.003$ & $0.06 \pm 0.005$ & $0.09 \pm 0.009$ \\
\hline \multirow{2}{*}{$24 \mathrm{hrs}$} & Radiation only & $0.41 \pm 0.015^{\mathrm{a} * * *}$ & $0.26 \pm 0.024^{\mathrm{a}^{* *}}$ & $0.37 \pm 0.02 \mathrm{I}^{* * * *}$ & $0.06 \pm 0.008^{a^{*}}$ & $0.10 \pm 0.003^{\mathrm{a}^{* *}}$ & $0.19 \pm 0.007^{\mathrm{a}^{* * *}}$ \\
\hline & Radiation + PBL treated & $0.27 \pm 0.032^{\text {b** }}$ & $0.22 \pm 0.047^{b^{*}}$ & $0.33 \pm 0.029^{b^{*}}$ & $0.06 \pm 0.006$ & $0.08 \pm 0.00 \mathrm{l}^{\mathrm{b} *}$ & $0.17 \pm 0.004$ \\
\hline \multirow{2}{*}{$\begin{array}{l}48 \\
\text { hrs }\end{array}$} & Radiation only & $0.34 \pm 0.012$ & $0.24 \pm 0.025$ & $0.25 \pm 0.036$ & $0.06 \pm 0.004$ & $0.09 \pm 0.003$ & $0.15 \pm 0.008$ \\
\hline & Radiation + PBL treated & $0.27 \pm 0.015^{c^{*}}$ & $0.21 \pm 0.018^{\mathrm{c}^{*}}$ & $0.21 \pm 0.027^{\mathrm{c}^{*}}$ & $0.04 \pm 0.005^{c^{*}}$ & $0.07 \pm 0.002$ & $0.12 \pm 0.009^{*}$ \\
\hline
\end{tabular}

Animals were divided into three groups: control, radiation only $(R O)$ and PBL extract pretreated irradiated (D + R); Tissue homogenates, mixed with TBA-TCA solution were boiled, cooled and centrifuged; Absorbance of the supernatants was measured at $535 \mathrm{~nm}$; The experiment was performed in triplicate with three animals in each group; Lipid peroxidation was expressed as nanomoles of MDA formed $\times 10^{6} / g r a m$ of protein; Values represent mean \pm SD of three independent experiments and level of significance of the difference is expressed in terms of p-values; ${ }^{a}$ radiation only ( 24 hrs) vs. control (saline treated); ' ${ }^{b}$ radiation + PBL treated ( $\left.24 \mathrm{hrs}\right)$ vs. radiation only $(24 \mathrm{hrs})$; ' radiation + PBL treated (48 hrs) vs. radiation only (48 hrs); ${ }^{*} \mathrm{p}<0.05,{ }^{* *} \mathrm{p}<0.01,{ }^{* * *} \mathrm{p}<0.001$.

atom from their hydroxyl group to radicals and results in the formation of less reactive flavonoid phenoxyl radicals. ${ }^{15}$ Most of the plant preparations reflect high antioxidant potential due to possession of larger quantity of polyphenols. During current study, PBL extract has been reported to have significant potential to chelate metal ions and to scavenge free radicals which was elucidated by its property to scavenge DPPH and superoxide radicals under in vitro systems. These findings are in corroboration to the earlier reports. ${ }^{13,14,16}$ Flora et al. ${ }^{17,18}$ recently suggested significant delineation in metal induced biochemical alterations following administration of synthetic and natural antioxidants. PBL has also revealed the properties of good electron donor, thus showing its reducing ability by converting $\mathrm{Fe}^{3+}$ to $\mathrm{Fe}^{2+}$. These properties are attributed to the presence of polyphenols in the extract. Bioactive phenolic components of Piper betle, like hydroxychavicol, chevibetol and pyrocatechol are reported repeatedly ${ }^{5,13,19}$ for reflecting free radical scavenging activity. Our preparation of Piper betle (PBL extract) in aqueous form also appears to be working on the similar principle due to presence of these phenolic components.

It is amply explained that gamma radiation induces damage mainly by the generation of free radicals by indirect mode of action. ${ }^{6}$ Initially generated free radicals get multiplied and converted into more powerful hydroxyl radicals $\left(\mathrm{OH}^{*}\right)$ in the presence of trace metal anion. These hydroxyl radicals induce oxidative deterioration of lipids by the process lipid peroxidation which

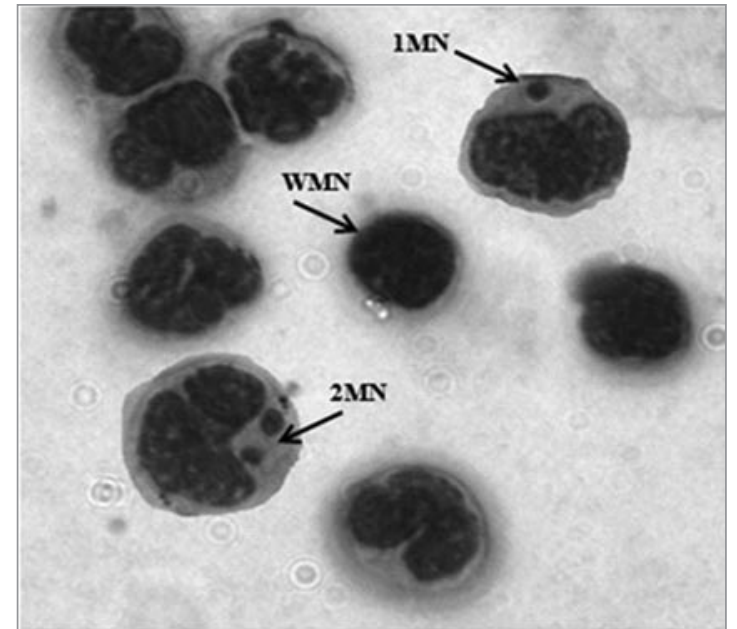

Figure 8. Mouse bone marrow cells with micronuclei $(\mathrm{MN})$ viewed at 100X under trinocular microscope. Cells with micronuclei were counted in bone marrow of Swiss albino mice at $24 \mathrm{~h}$ after whole body gamma irradiation (200 cGy). Pre-irradiation treatment of animals with PBL effectively protected bone marrow cells and frequency of micronucleated cell formation was significantly inhibited. WMN, Bone marrow cell without micronuclei; IMN, Bone marrow cell with one micronucleus; $2 \mathrm{MN}$, Bone marrow cell with two micronuclei. 


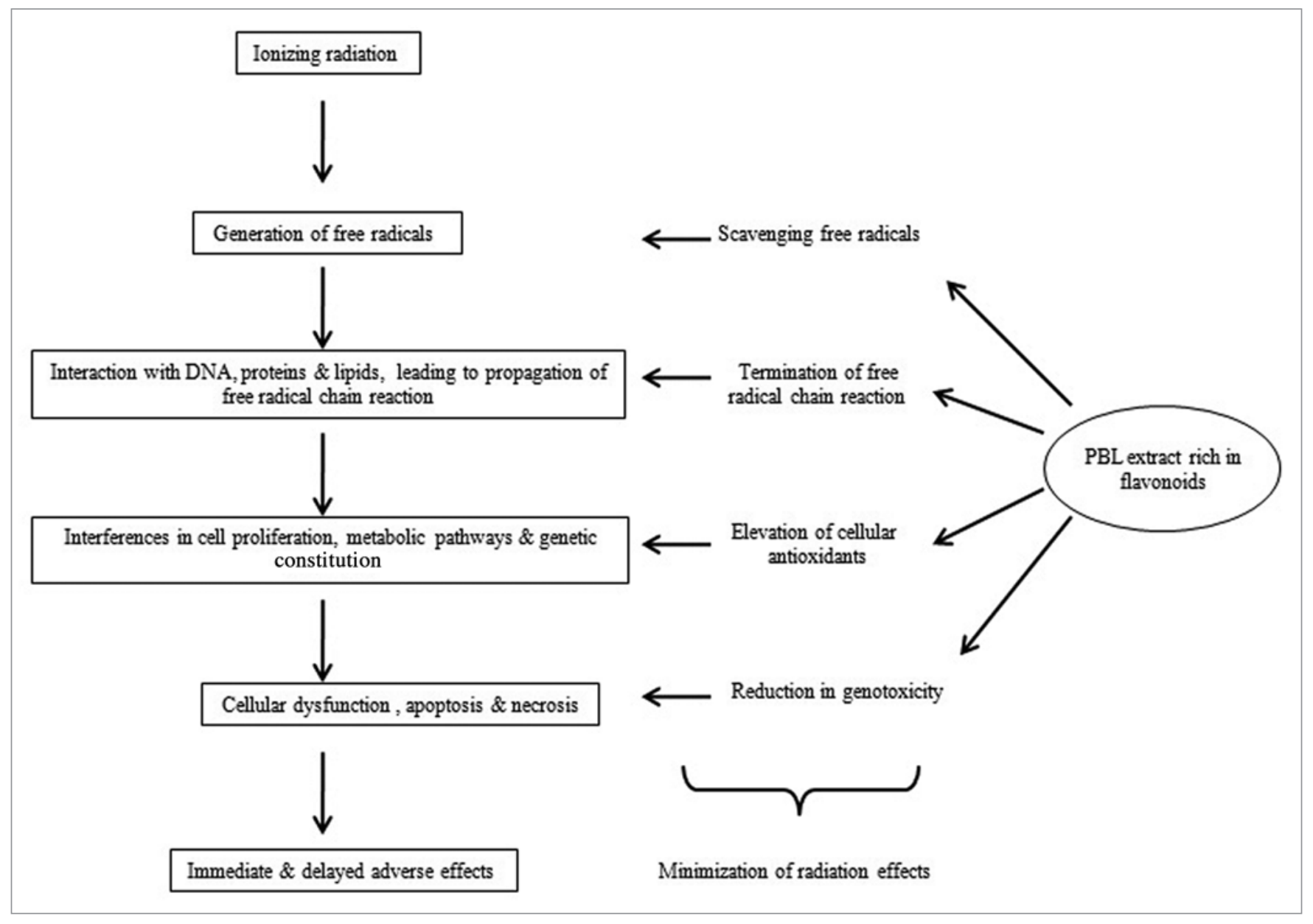

Figure 9. Diagrammatic representation showing potential pathways of injury by ionizing radiation and possible mechanism of radioprotection rendered by Piper betle leaf extract.

results into the formation of fatty acid radicals. These radicals later react with molecular oxygen and produce other generation of free radicals which disrupts cellular integrity by attacking on cellular membranes. ${ }^{20}$ The cycle continues until an antioxidant acts as chain terminator. Pre-irradiation treatment of PBL extract resulted into significant reduction of lipid peroxidation (Table 1) clearly expressed its ability to scavenge chain propagating free radicals and minimizing metal ions involved in fenton reaction. Under in vitro investigation also, decrease in the concentration of TBARS with increased concentration of extract was reported which further strengthen the anti-lipid peroxidation activity of PBL extract.

The total antioxidant capacity of plasma which was measured in terms of its ferric reducing ability declined sharply as a result of $\gamma$-radiation induced damage in plasma. ${ }^{21,22}$ Herbal preparations are well documented in exerting their antioxidant potential multidirectionally. They have been also reported to enhance reducing ability of plasma. ${ }^{21,23}$ In consonance, our findings on PBL extract led to significant increase in plasma reducing ability (Fig. 7) and thus helping in restoring its antioxidant potential. Glutathione, non enzymatic antioxidants produced in body, a linear tripeptide, plays a pivotal role in maintenance of the balance of cellular redox status. It directly quenches reactive hydroxyl free radicals and protects the cells and tissues from lipid peroxidation. Whole body irradiation of animals resulted in depletion of GSH content in different tissues due to the oxidation of GSH with the free radicals resulting in the formation of thiyl radicals that react to produce oxidized glutathione (GSSG) which is toxic to the cells. Depletion in GSH causes elevation in hydroxyl radicals which in turn attack on lipid membranes and results in lipid peroxidation. ${ }^{24}$ In our observation also a similar correlation was observed between depletion of GSH and increase in LPx.

DNA breaks and fragments resulted from chromosomal damage appear as micronuclei in rapidly proliferating cells. Various plants flavonoids have been reported to provide protection against induction of micronuclei by radiation and this property of flavonoids might be attributed to their direct hydroxyl radical scavenging potency. ${ }^{1,25}$ Being rich in flavonoids PBL extract has also indicated reduced percentage of micronucleated cells reflecting protection to DNA against ionizing radiation. Finally, oral administration of the PBL extract before irradiation mitigate the deleterious effect of radiation predominantly by scavenging the free radicals, acting as chain breaking antioxidant, inhibiting the lipid peroxidation, elevating the level of endogenous antioxidants 
and reducing the frequency of micro nucleated cells. Pathways reflecting radiation injury and possible mechanism of action for their mitigation are summarized in Figure 9.

Studies on Piper betle leaf extracts, to ameliorate the oxidative stress is still in the stage of infancy but the preliminary data obtained from the current study suggests the possible role of this plant extract in treatment of the free radicals mediated diseases. Supported with significant number of reports on almost non toxic status of this extract even after large, multiple and consecutive doses of this extract, make it safe in abating radiotherapy inflicted normal tissue injuries. In addition, this extract might be of immense use in mitigating damaging effects infused during whole body exposure to moderate doses of ionizing radiation. Though an elaborative work in this direction is warranted before making any further statement.

\section{Materials and Methods}

Chemicals. 1,1-Diphenyl-2-picryl hydrazyl (DPPH), bovine serum albumin (BSA) ascorbic acid, $\alpha$-tocopherol, quercetin, 5,5'-dithio-bis(2-Nitrobenzoic Acid) (DTNB) and aluminium chloride $\left(\mathrm{AlCl}_{3}\right)$ were procured from Sigma Chemical Co., (St. Louis, USA). Folin Ciocalteu reagent (FCR), trichloroacetic acid (TCA), thiobarbituric acid (TBA), nitro blue tetrazolium chloride (NBT), potassium ferricyanide,2,4,6,Tri-(2-Pyridyl)-1,3,5-triazine (TPTZ), m-phosphoric acid, sodium carbonate $\left(\mathrm{Na}_{2} \mathrm{CO}_{3}\right)$, sodium hydroxide $(\mathrm{NaOH})$ and ferric chloride $\left(\mathrm{FeCl}_{3}\right)$ were from SRL and gallic acid (GA), butylated hydroxy toluene (BHT) and sodium nitrite $\left(\mathrm{NaNO}_{2}\right)$ were purchased from Merck Co., (Germany). All the other chemicals used were of commercially high purity and analytical grade.

Plant material. The fresh leaves of Piper betle, identified by institute's botanist, were collected from Central market of Delhi, India. The plant material was made free from dust and insects by repeated washing in free flowing water. The leaves were chopped, mixed with de-ionized water and grounded. The resultant mixture was filtered through Whatman no.1 filter paper. The filtrate was dried under vacuum evaporation and stored in air tight containers in refrigerator. The preparation was analytically examined to rule the possibilities of any metal contamination and finally prepared super fine powder was assigned the name PBL extract as code.

Animals and $\gamma$-ray irradiation. Swiss albino Strain 'A' female mice $(26 \pm 2 \mathrm{~g}), 8-10$ weeks old, fed with standard food pellet and water ad libitum were used for study. They were housed in polypropylene cages bedded with sterilized rice husk under the control environmental conditions $\left(24 \pm 2^{\circ} \mathrm{C} ; 12 \mathrm{hrs}\right.$ alternating dark and light cycle). The experiments were conducted strictly adhering to the guidelines of the Institutional Animal Ethics Committee (IAEC). Mice were exposed in ${ }^{60} \mathrm{Co}$., gamma chamber (Model-220, Atomic Energy of Canada Ltd.,) at the dose rate of $0.33 \mathrm{cGy} / \mathrm{sec}$. Fresh air was circulated continuously in the irradiation chamber to avoid hypoxic conditions. Dosimetry was carried out using Baldwin Farmer's secondary dosimeter and Fricke's chemical dosimetry method.
In-vitro studies. Total phenolic content determination. Total phenols in the aqueous PBL extract were evaluated by using Folin ciocalteu reagent. ${ }^{26}$ The aliquots containing different concentration of the extract/Gallic acid (standard phenolic compound) were mixed with $5 \mathrm{ml}$ of $1 \mathrm{~N} \mathrm{FCR}$ and $4 \mathrm{ml}$ of $1 \mathrm{M} \mathrm{Na}_{2} \mathrm{CO}_{3}$. The mixtures were allowed to stand for $15 \mathrm{~min}$ and the total phenols were determined by colorimetry at $765 \mathrm{~nm}$. The standard curve was prepared by using different concentrations of gallic acid $(10-100 \mu \mathrm{g} / \mathrm{ml})$. Total phenolic content was expressed as $\mu \mathrm{M}$ gallic acid equivalent (GAE) using the equation based on the calibration curve: $y=0.0225 x-0.1164, r^{2}=0.9315$, where $y$ was the absorbance and $\mathrm{x}$ was GAE $(\mu \mathrm{M} / \mathrm{mg})$.

Total flavonoids determination. Total flavonoids in the PBL extract were measured using the method of Zhishen et al. 1999. ${ }^{27}$ Briefly, various concentrations of the extract/quercetin were mixed with $0.03 \mathrm{ml}$ of $5 \% \mathrm{NaNO}_{2}$ and $10 \% \mathrm{AlCl}_{3}$ and incubated at room temperature for $5 \mathrm{~min}$. After adding $0.2 \mathrm{ml} \mathrm{NaOH}$ and $0.24 \mathrm{ml}$ double distilled water, absorbance was measured at $510 \mathrm{~nm}$. The standard curve was plotted using different concentrations of quercetin $(50-1,000 \mu \mathrm{g} / \mathrm{ml})$. Total flavonoids content was calculated by calibration curve based equation: $\mathrm{y}=0.0008 \mathrm{x}+0.0621, \mathrm{r}^{2}=0.9867$ where $\mathrm{y}$ and $\mathrm{x}$ was the absorbance and quercetin equivalent $(\mu \mathrm{g} \mathrm{QE} / \mathrm{mg}$ ) respectively.

Antioxidant activity. DPPH radical scavenging assay. The stable 1,1-diphenyl-2-picryl hydrazyl (DPPH) was used for determination of free radical scavenging activity of PBL extract. ${ }^{28}$ In brief, different concentrations of test samples with $1 \mathrm{ml}$ methanolic DPPH $(0.1 \mathrm{mM})$ were incubated at room temperature for $30 \mathrm{~min}$ in dark and absorbance was recorded at $517 \mathrm{~nm}$. Ascorbic acid and BHT were used as reference while methanol and DPPH mixed in equal amounts served as control. The percent DPPH free radical scavenging for all the test samples was calculated.

Superoxide scavenging assay. Superoxide scavenging was assayed by the method of Govindrarajan et al. 2003. ${ }^{29}$ Alkaline dimethyl sulfoxide (DMSO) was used as a superoxide generating system. Briefly, to $0.5 \mathrm{ml}$ of different concentrations of test sample, 1 $\mathrm{ml}$ of alkaline DMSO and $20 \mathrm{mM}$ NBT in phosphate buffer $(\mathrm{pH}$ 7.4) were added. Absorbance of the test mixtures was recorded at $560 \mathrm{~nm}$. BHT and $\alpha$-tocopherol were used as standard antioxidants for comparison. The percent superoxide radicals scavenging was calculated for each sample individually.

Metal chelating activity. Metal chelating activity was estimated by using method reported by Benzie and Strain, 1996. ${ }^{30}$ Varying concentrations of test samples were dissolved in $1 \mathrm{ml}$ of $0.05 \%$ o-phenanthroline in methanol and $2 \mathrm{ml}$ ferric chloride $(200 \mu \mathrm{M})$. After $10 \mathrm{~min}$ incubation at room temperature, absorbance was measured at $510 \mathrm{~nm}$. Ascorbic acid and BHT were used as reference. The metal chelating activity was calculated in terms of percent scavenging.

Reducing power assay. Oyaizu, 1986 method $^{31}$ was followed for this assay. In brief, different concentrations of the test samples $(50 \mu \mathrm{l})$, mixed with $200 \mu \mathrm{l}$ phosphate buffer $(0.2 \mathrm{M}$, $\mathrm{pH}$ 6.5) and $0.1 \%$ potassium ferricyanide, were incubated at $50^{\circ} \mathrm{C}$ for $20 \mathrm{~min}$. Addition of $10 \%$ TCA $(250 \mu \mathrm{l})$ to the mixtures was followed by centrifugation at $6,000 \mathrm{rpm}$ for $10 \mathrm{~min}$. 
The resulting supernatants mixed with $500 \mu \mathrm{l}$ double distilled water and $100 \mu \mathrm{l}$ of $0.1 \%$ ferric chloride were further incubated at $30^{\circ} \mathrm{C}$ for $10 \mathrm{~min}$ and absorbance was measured at $700 \mathrm{~nm}$. The color development was recorded against blank containing phosphate buffer, potassium ferricyanide and TCA. The control antioxidant BHT was utilized to compare reducing power.

Lipid peroxidation assay (LPX). Anti-lipid peroxidation property of PBL extract was measured by using John et al. 1984 method. ${ }^{32}$ Brain tissues of anesthetized mice, excised carefully after decapitation, were homogenized with cold 0.15 M KCL to make $10 \%$ homogenate. Brain homogenate $(0.5 \mathrm{ml})$ was added to $1 \mathrm{ml}$ of various concentrations of the extract and incubated at $37^{\circ} \mathrm{C}$ for $30 \mathrm{~min}$. Lipid peroxidation was induced in the homogenate by exposure to ionizing radiation $(25,000 \mathrm{cGy})$. Various concentrations of extract/BHT with $2 \mathrm{ml}$ of TCA-TBA solution (15\% w/v TCA- $0.37 \% \mathrm{w} / \mathrm{v}$ TBA) were boiled, cooled and centrifuged at $1,000 \mathrm{rpm}$ for $10 \mathrm{~min}$. The absorbance of the supernatants was recorded at $536 \mathrm{~nm}$ and percent inhibition of lipid peroxidation was calculated.

Total antioxidant activity (FRAP). Ferric reducing antioxidant property of the extract was analyzed by using the modified method of Benzie and Strain, $1996 .{ }^{30}$ The fresh working FRAP solution prepared by mixing $50 \mathrm{ml}$ acetate buffer (300 mM), $5 \mathrm{ml} \mathrm{TPTZ}(10 \mathrm{mM})$ and $5 \mathrm{ml} \mathrm{FeCl} \cdot 6 \mathrm{H}_{2} \mathrm{O}$ (20 mM), was incubated at $37^{\circ} \mathrm{C}$ before use. Thereafter, to the different concentrations of the test samples, $3 \mathrm{ml}$ working FRAP solution was added and allowed to stand in dark for $30 \mathrm{~min}$. Absorbance of the colored mixtures was recorded at $593 \mathrm{~nm}$. Results were calculated by using equation based on the calibration curve: $\mathrm{y}=0.0007 \mathrm{x}-0.0068, \mathrm{r}^{2}=0.9992$ where $\mathrm{y}$ was the absorbance and $\mathrm{x}$ was $\mu \mathrm{M} \mathrm{Fe}(\mathrm{II}) / \mathrm{mg}$ sample. Ascorbic acid, quercetin and BHT were used as reference.

In vivo studies. Experimental protocol. The animals (Swiss albino Strain 'A' female mice) were divided into three groups with three animals in each group: control, radiation only and radiation + PBL extract treated. The animals in control group were orally administered $250 \mu \mathrm{l}$ normal saline only. Radiation only group animals were irradiated with a dose of $500 \mathrm{cGy}$. In Radiation + PBL treated group, mice were orally administered with aqueous extract of PBL (225 mg/kg b.w.) one hour prior to $500 \mathrm{cGy}$ exposure. For micronucleus assay $200 \mathrm{cGy}$ dose was used. The animals were dissected at $24 \mathrm{hrs}$ and $48 \mathrm{hrs}$ after exposure to gamma radiation. Each experiment was repeated in triplicate.

Preparation of mice tissue homogenate. The animals were dissected after cervical dislocation. Different organs such as brain, liver, kidney, spleen, thymus and jejunum were excised and homogenized individually in cold buffered saline $(\mathrm{pH} 7.4)$ to make $10 \%$ homogenate. Blood was drawn from the heart puncture of the animals.

Ferric reducing activity of plasma (FRAP). The antioxidant potential of plasma was evaluated by its ferric ions reducing ability. ${ }^{30}$ In brief, plasma was separated from the blood drawn by heart puncture of mice. The plasma, diluted with water in 1:4 ratio, was mixed with freshly prepared FRAP solution. After incubation for $10 \mathrm{~min}$. in dark, OD was taken at $593 \mathrm{~nm}$. Formation of $\mu \mathrm{M} \mathrm{FeSO}_{4}$ was calculated based on the standard curve $(100 \mu \mathrm{l}-1,000 \mu \mathrm{l})$.

Lipid peroxidation determination. Lipid peroxidation (LPx) level in different tissues was estimated by the method of Beuge and Aust, $1978 .{ }^{33}$ Tissues homogenate $(100 \mu \mathrm{l})$, prepared in phosphate buffer saline ( $\mathrm{pH} 7.4$ ), was mixed with $15 \%$ TCA followed by addition of $0.37 \%$ TBA. The samples boiled at $95^{\circ} \mathrm{C}(30 \mathrm{~min})$ were centrifuged and absorbance of the supernatants was recorded at $535 \mathrm{~nm}$. The concentration of TBARS was determined by using an extinction coefficient of $1.56 \times 10^{5} \mathrm{M}^{-1} \mathrm{~cm}^{-1}$. Result was expressed as nanomoles of MDA formed per gram of protein.

Antioxidant glutathione (GSH) determination. Beutler et al. 1975 method $^{34}$ was followed to determine GSH concentration in different tissues excised from experimental mice. Briefly, the proteins of the samples were precipitated by adding precipitating solution (1.67\% metaphosphoric acid + 0.2\% EDTA $+30 \%$ $\mathrm{NaCl})$. The samples were centrifuged and to the $2 \mathrm{ml}$ of filtrate, $8 \mathrm{ml}$ phosphate solution $(0.3 \mathrm{M})$ and DTNB (40 $\mathrm{mg}$ in $1 \% 100 \mathrm{ml}$ sodium citrate) was added. The absorbance was recorded at $412 \mathrm{~nm}$. Glutathione concentration was expressed as $\mu \mathrm{g} \mathrm{GSH} / \mathrm{mg}$ protein.

Micronucleus (MN) assay. Micronuclei were scored in mouse bone marrow cells by the method described by Chaubey et al. 1993. ${ }^{35}$ The animals were sacrificed $24 \mathrm{hrs}$ after irradiation. Both the femurs were taken out from each animal and bone marrow cells were aspirated in PBS with the help of syringe. The suspension was centrifuged, mixed with few drops of fetal bovine serum and smear was drawn on clean slides. After fixing in methanol, the slides were stained for $10 \mathrm{~min}$ with May-Grunwald Giemsa stain diluted in Sorensen's buffer ( $\mathrm{pH}$ 6.8). The slides were mounted in DPX and observed under microscope. For each animal 1,000 cells were scored and percentage of micronucleated cells was calculated.

Protein determination. Protein contents were measured by Bradford, 1976 method. ${ }^{36}$ Standard curve was plotted by using different concentrations of bovine serum albumin (BSA) as a standard.

Statistical analysis. For in vitro studies, the experiment results were expressed as mean \pm SEM of three replicates. $\mathrm{IC}_{50}$ values were calculated by using linear regression analysis. Student's t-test was used for analyzing the data of in-vivo studies. A value of $\mathrm{p}<0.05$ was considered as statistically significant.

\section{Acknowledgements}

The authors thank Dr. R.P. Tripathi, Director INMAS for his support and encouragement. Financial assistance from Defense Research and Development Organization (DRDO) is gratefully acknowledged. 


\section{References}

1. Hosseinimehr SJ. Trends in the development of radioprotective agents. Drug Discov Today 2007; 12:794805.

2. Jagetia GC. Radioprotective potential of plants and herbs against the effects of ionizing radiation. J Clin Biochem Nutr 2007; 40:74-81.

3. Ozsachin M, Betz M, Matzinger O, Bron L, Luthi F, Pasche P, et al. Feasibility and efficacy of subcutaneous amifostine therapy in patients with head and neck cancer treated with curative accelerated concomitant-boost radiation therapy. Arch Otolaryngol Head Neck Surg 2006; 132:141-5.

4. Adhikary P, Banerji J, Chowdhury D, Das AK, Deb CC, Mukherjee SR, Chatterjee A. Antifertility effect of Piper betle Linn. extract on overy and testis of albino rats. Ind J Exp Biol 1989; 27:868-70.

5. Choudhury D, Kale RK. Antioxidant and nontoxic properties of Piper betle leaf extract: in-vitro and in-vivo studies. Phytother Res 2002; 16:461-6.

6. Sankaranarayanan K. Estimation of the genetic risks of exposure to ionizing radiation in human: Current status and emerging perspectives. J Radiat Res 2006; 47:57-66.

7. Gems D, Partridge L. Stress-response hormesis and aging: that which does not kill us makes us stronger. Cell Metab 2008; 7:200-3.

8. Nikola G. Anti-ageing and ageing factors in life: The role of free radicals. Radiat Phys Chem 2007; 76:157786.

9. Chatterjee A, Pakrashi SC. In: Treatise of Indian Medicinal Plants, CSIR Publication New Delhi 1995; 1:26-35.

10. Prabhu MS, Platel K, Saraswhati G, Srinivasan K Effect of orally administered betel leaf (Piper betle Linn.) on digestive enzymes of pancreas and intestinal mucosa and on the bile production in rats. Ind J Exp Biol 1995; 33:752-6.

11. Saravanan R, Prakasam A, Ramesh B, Pugalendi KV Influence of Piper betle on hepatic marker enzymes and tissue antioxidant status in ethanol treated Wister rats. J Med Food 2002; 5:197-204
12. Kanjwani DG, Marathe TP, Chiplunkar SV, Sathaye SS. Evaluation of immunomodulatory activity of methanolic extract of Piper. Scand J Immunol 2008; 67:589 93.

13. Bhattacharya S, Subramanian M, Roychowdhury S, Bauri KA, Kamat JP, Chattopadhyay S, Bandyopadhyay SK. Radioprotective property of the ethanolic extract of Piper betel leaf. J Radiat Res 2005; 46:165-71.

14. Dasgupta N, Bratati De. Antioxidant activity of Piper betle L. leaf extract in vitro. Food Chem 2004; 88:21924.

15. Patel JM. A review of potential health benefits of flavonoids. Lethbridge Undergrad Res J 2008; 3.

16. Agbor Gabriel A, Vinson Joe A, Oben Julius E, Ngogang Jeanne Y. In vitro antioxidant activity of three Piper species. J Herb Pharmacother 2007; 7:49-64.

17. Flora SJS. Structural, chemical and biological aspects of antioxidants for strategies against metal and metalloid exposure. Oxid Med Cell Longev 2009; 3:191-206.

18. Flora SJS, Chouhan S, Kannan GM, Mittal M, Swarnakar H. Combined administration of taurine and monoisoamyl DMSA protects arsenic induced oxidative injury in rats. Oxid Med Cell Longev 2008; 1:39-45.

19. Amonkar AJ, Nagabhushan M, D'Souza AV, Bhide SV. Hydroxychavicol: a new phenolic antimutagen from Betel leaf. Fd Chem Toxicol 1986; 24:1321-4.

20. Sisodia R, Yadav RK, Sharma KV, Bhatia AL. Spinacia oleracea modulates radiation-induced biochemica changes in mice testis. Ind J Pharmaceut Sci 2008; 70:320-6.

21. Gupta ML, Sankhwar S, Verma S, Devi M, Samanta N, Agrawala PK, et al. Whole body protection to lethally irradiated mice by oral administration of semipurified fraction of Podophyllum hexandrum and post irradiation treatment of Picrorhiza kurroa. Tokai J Exp Clin Med 2008; 33:6-12.

22. Goel HC, Agrawala PK, Pathania V, Malhotra N. Immunomodulatory and cytoprotective role of RP-1 in $\gamma$-radiated mice. Mol Cell Biochem 2003; 254:73-81.

23. Dlugosz A, Lembas-Bogaczyk J, Lamer-Zarawska E. Antoxid increases ferric reducing antioxidant power (FRAP) even stronger than vitamin C. Acta Pol Pharm 2006; 63:446-8
24. Bhartiya US, Raut YS, Joseph LJ, Hawaldar RW, Rao BS. Evaluation of the radioprotective effect of turmeric extract and vitamin $\mathrm{E}$ in mice exposed to therapeutic dose of radioiodine. Ind J Clin Biochem 2008; 32:382 6.

25. Hosseinimehr SJ, Nemati A. Radioprotective effects of hesperidin against gamma irradiation in mouse bone marrow cells. Br J Radiol 2006; 79:415-8.

26. McDonald S, Prenzler PD, Autolovich M, Robards K. Phenolic content and antioxidant activity of olive extracts. Food Chem 2000; 73:73-84.

27. Zhishen J, Mengcheng T, Jianming W. The determination of flavonoid content in mulberry and their scavenging effects on superoxide radicals. Fd Chem 1999; 64:555-9.

28. Koleva II, Van Beek TA, Linssen JPH, de Groot A Evstatieva LN. Screening of plants extracts for antioxidant activity: a comparative study on three testing methods. Phytochem Anal 2002; 13:8-17.

29. Govindrarajan R, Vijayakumar M, Rawat AKS, Mehrotra S. Free radical scavenging potential of Picrorhiza kurrooa Royle ex Benth. Ind J Exp Biol 2003; 41:875-9.

30. Benzie IIF, Strain JJ. The ferric reducing ability of plasma (FRAP) as a measure of antioxidant power: the FRAP assay. Anal Biochem 1996; 239:70-6.

31. Oyaizu M. Anti-oxidative activity of browning products of glucosamine fractionated by organic solvent and thin layer chromatography. Nippon Shokuhin Kogyo Gakkaishi 1986; 35:771-5.

32. John A, Steven DA. Microsomal lipid peroxidation. Methods Enzymol 1984; 30:302-8.

33. Beuege JA, Aust SD. Microsomal lipid peroxidation. Methods Enzymol 1978; 30:302-10.

34. Beutler EUR. Reduced glutathione-GSH, u: Beutler E. (ur.) Red cell metabolism: A manual of biochemical methods, New York: Grane and Straton 1975.

35. Chaubey RC, Bhilwade HN, Joshi BN, Chauhan PS. Studies on migration of micronucleated erythrocytes from bone marrow to the peripheral blood in irradiated swiss mice. Int J Radiat Biol 1993; 63:239-45.

36. Bradford M. A rapid and sensitive method for the quantitation of microgram quatities of protein utilizing the principle of protein-dye binding. Anal Biochem 1976; 72:248-54. 


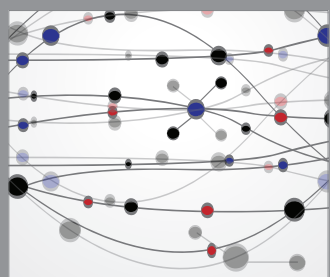

The Scientific World Journal
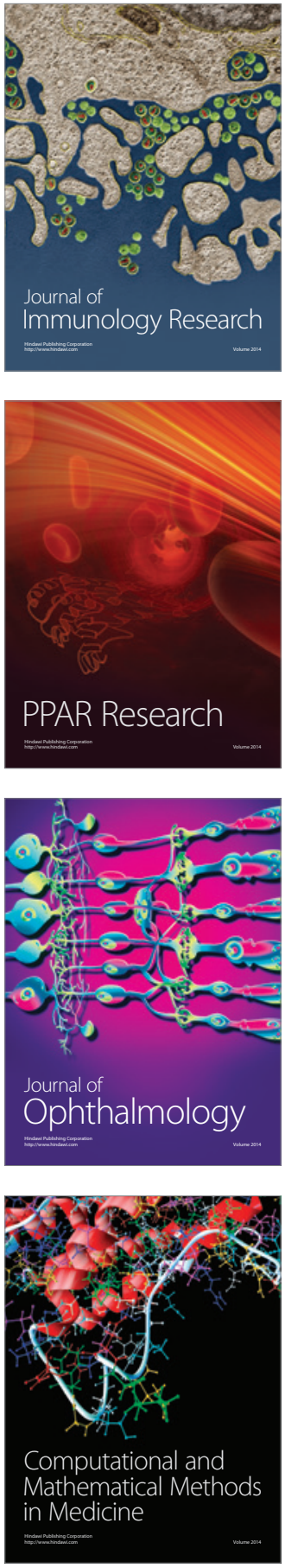

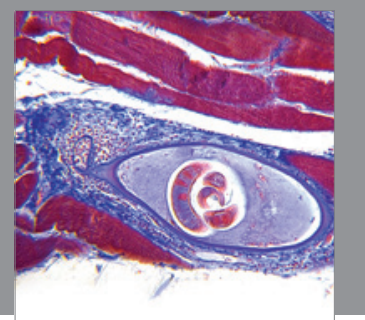

Gastroenterology

Research and Practice
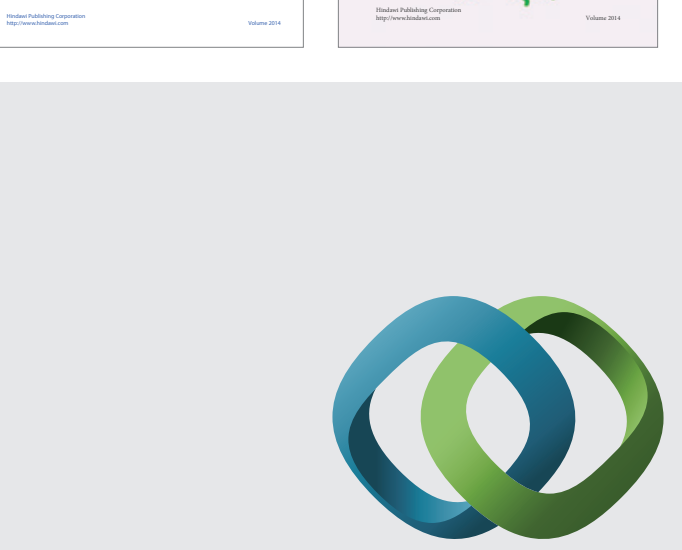

\section{Hindawi}

Submit your manuscripts at

http://www.hindawi.com
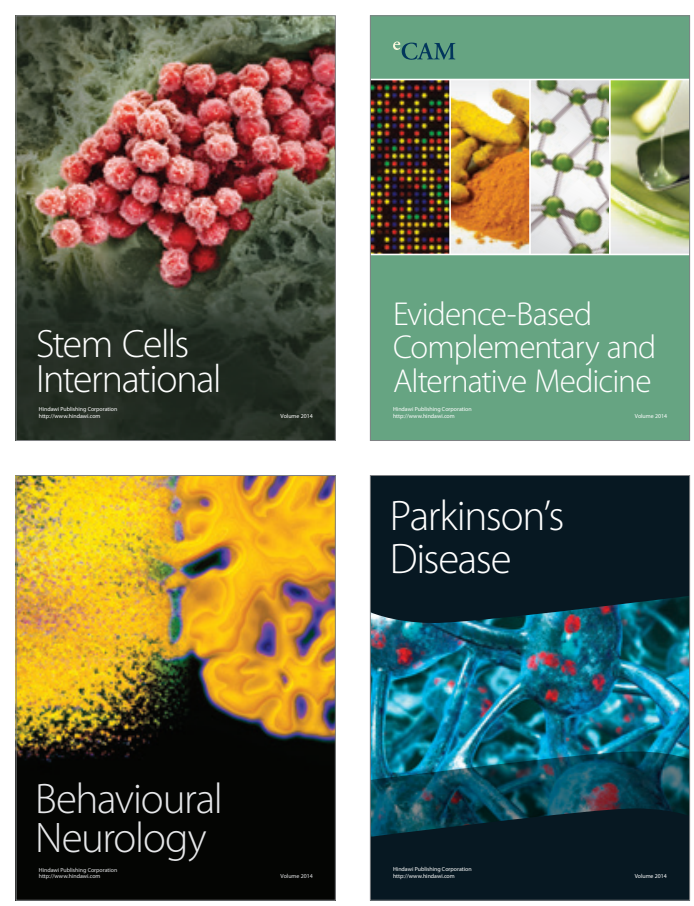

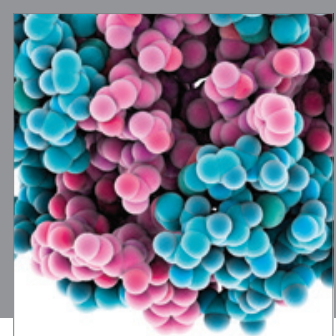

Journal of
Diabetes Research

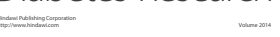

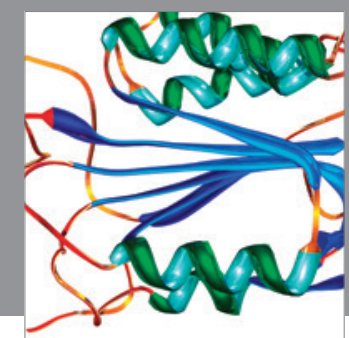

Disease Markers
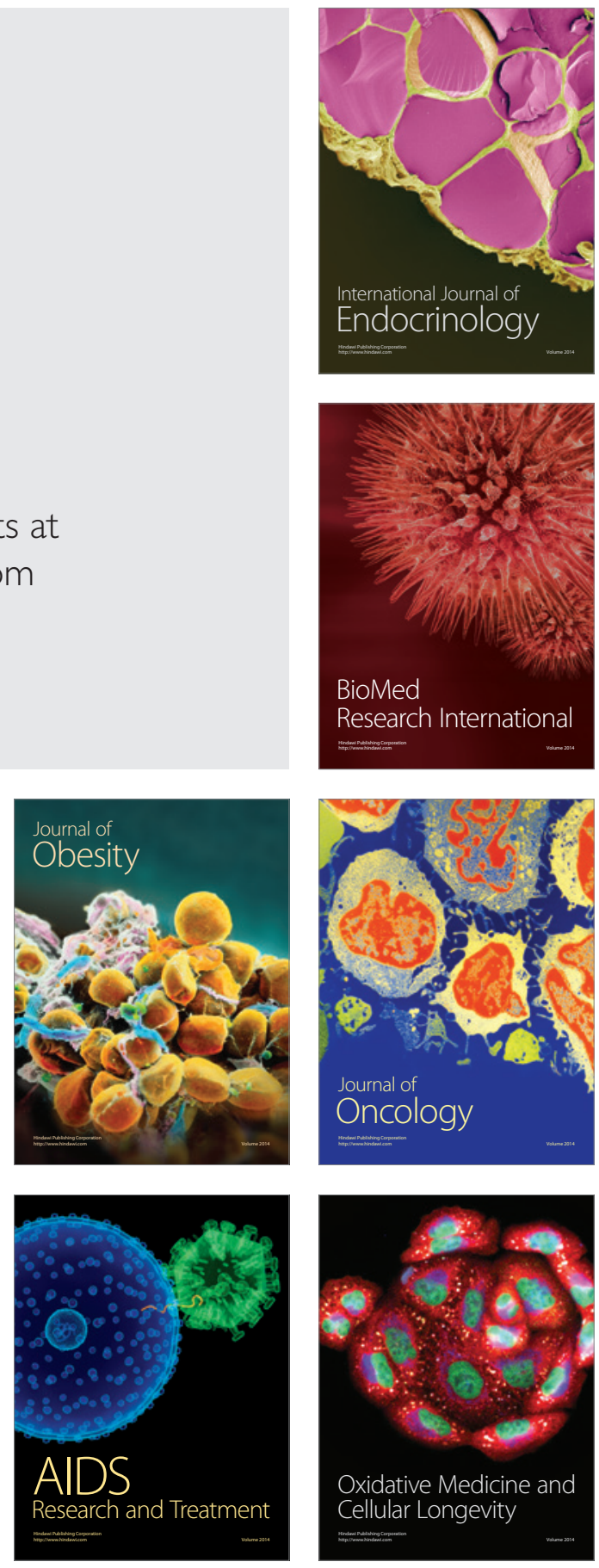